\title{
Protection effect of taurine on nitrosative stress in the mice brain with chronic exposure to arsenic
}

\author{
Ning $\mathrm{Ma}^{1 *}$, Mikio Sasoh² ${ }^{2}$ Shosuke Kawanishi ${ }^{1}$, Hiromichi Sugiura ${ }^{1}$, Fengyuan Piao ${ }^{3}$ \\ From $17^{\text {th }}$ International Meeting of Taurine \\ Fort Lauderdale, FL, USA. 14-19 December 2009
}

\begin{abstract}
Background: Arsenic exposure induces overproduction of reactive nitrogen species (RNS) in brain tissue and results in nucleic acid damage to the nerve cells. The 8-nitroguanine is one of the major products formed by the reaction of guanine, and $\mathrm{ONOO}^{-}$, and has been used as a popular biomarker of nucleic acid damage due to RNS attacking. In the present study, we examined whether the administration of taurine can protect against nucleic acid damage of brain neurons by arsenic-induced RNS.
\end{abstract}

Materials and methods: Sixty mice (30 male and 30 female) weighing $19.5 \pm 1.5 \mathrm{~g}$ were divided into 3 groups: (1) control group, (2) experimental group that received arsenic $\left(\mathrm{As}_{2} \mathrm{O}_{3}\right)$, and (3) antagonistic group that received taurine with arsenic. Arsenic was administered for 60 days. 8-Nitroguanine expressions in brain neurons of mice were examined by the immunohistochemical method. Histopathological changes in brain tissues of mice were observed under light microscope and the immunohistochemistry method was used to investigate 8-nitroguanine expressions in cerebrum and cerebellum of mice.

Results: In the control group, no abnormal histopathological changes were observed in brain tissue of the mice. In brain tissue of the mice exposed to arsenic, histopathological results showed swells, evident vacuolar degeneration in cytoplasm, karyorrhexis and karyolysis. Relatively light pathological changes were observed in brain of the mice co-administered arsenic and taurine. Little or no expression of 8-nitroguanine in brain tissue was observed in controls. However, intensive expression of 8-nitroguanine was found in brain tissue of mice exposed to arsenic and it was mainly distributed in nucleus neighbouring the nuclear membrane, but a little in cytoplasm. A weak expression of 8-nitroguanine was observed in brain cells of mice co-administered arsenic and taurine.

Conclusions: The brain neurons may be the major target cells of arsenic neurotoxicity. Co-administration of arsenic and taurine can alleviate DNA damage of brain neurons caused by arsenic through the RNS signal pathway.

\section{Background}

Arsenic is a naturally occurring element that is ubiquitously present in the environment. High concentration of naturally occurring arsenic in drinking water is a major health problem in different parts of the world. Arsenic is an environmental contaminant found naturally in ground water. Drinking water contamination by

\footnotetext{
*Correspondence: maning@suzuka-u.ac.jp

'Faculty of Health Science and Institute of Traditional Chinese Medicine,

Suzuka University of Medical Science, Suzuka, Mie 510-0293, Japan

Full list of author information is available at the end of the article
}

arsenic remains a major public health problem [1]. Acute and chronic arsenic exposure via drinking water has been reported in many countries of the world. There are sufficient epidemiological evidences revealing a causal association between arsenic exposure and human disease. Arsenic is also a neurotoxical substance. Drinking water containing arsenic exceeding $10 \mu \mathrm{g} / \mathrm{L}$ is harmful to the body [2]. Arsenic contamination also results from industrial and agricultural uses [3]. The adverse effect of acute and sub-chronic exposures to arsenic on the nervous system has been receiving more

\section{Biomed Central}

(c) 2010 Ma et al; licensee BioMed Central Ltd. This is an open access article distributed under the terms of the Creative Commons Attribution License (http://creativecommons.org/licenses/by/2.0), which permits unrestricted use, distribution, and reproduction in any medium, provided the original work is properly cited. 
and more attention. Epidemiological research demonstrated that exposure to arsenic results in impaired learning and concentration for studying, and deteriorated pattern memory and attention deficits in humans $[4,5]$. It was shown in animal experiments that arsenic could pass through the blood-brain barrier and invade the brain parenchyma, and there was a noticeable correlation between the dose of arsenic exposure and its concentration in the brain of guinea pigs and rats. Arsenic exposure renders the brain tissue vulnerable to radical attack resulting in abnormal apoptosis of neural cells. However, the mechanism of arsenic induced neurotoxicity is unclear to date [6]. It is known that arsenic exposure induces overproduction of reactive oxygen species (ROS) and reactive nitrogen species (RNS) in the body and results in nucleic acid damage to the nerve cells [7], which is one of mechanisms of arsenic toxicity. Therefore, it indicated that adverse effect of arsenic on bio-macromolecule maybe avoided or mitigated by intervention of antioxidants.

8-Nitroguanine is a mutagenic nitrosative DNA lesion caused by reactive nitrogen and oxygen species, and now has been used as a potential biomarker of inflammation-related cancers [8]. In the present study, 8-nitroguanine was used as a biomarker of nucleic acid damage [9]. We examined by the immunohistochemical method the interfering effects of taurine as antioxidants on nucleic acid damage of mice brain tissue exposed to arsenic to provide experimental evidences for prevention and therapy for the arsenic induced brain damage.

\section{Materials and methods Animal}

Sixty mice (Slc/ICR, 30 male and 30 female) weighing $19.5 \pm 1.5 \mathrm{~g}$ were purchased from Japan SLC (Shizuoka, Japan) and maintained under specific pathogen free conditions at the Institute for Laboratory Animals of Suzuka University of Medical Science. They were caged under a $12 \mathrm{~h}$ dark-light cycle in standard conditions of temperature (18-22 C) and humidity (50\%). The animals were maintained on a standard diet and water ad libitum. The animal experiment was performed in accordance with the Animal Guideline of Suzuka University of Medical Science and in agreement with the Ethical Committee of Suzuka University of Medical Science. Mice were 6 weeks old at the beginning of each experiment. All the mice were sex matched and weighed before the beginning of the experiment and pooled together. From this pool, the mice were randomly assigned to three different groups of twenty each. Group 1 received drinking water alone (as controls). Group 2 received $4 \mathrm{mg} / \mathrm{L}$ arsenic trioxide (as experimental group). Group 3 received both of $4 \mathrm{mg} / \mathrm{L}$ arsenic trioxide and $150 \mathrm{mg} / \mathrm{kg}$ taurine (as antagonistic apply group).
Arsenic trioxide was given through drinking water for 60 days and taurine was affused to the stomach twice a week. After the last administration, mice were deeply anesthetized with an intraperitoneal injection of sodium pentobarbital $(30 \mathrm{mg} / \mathrm{kg})$ and were perfused transcardially with phosphate-buffered saline (PBS; $0.01 \mathrm{M}$ sodium phosphate buffer, $\mathrm{pH} 7.4,150 \mathrm{mM} \mathrm{NaCl}$ ) for 1$2 \mathrm{~min}$., followed by a fixative, containing $4 \%$ paraformaldehyde, in PBS, pH 7.0. After the perfusion, the brains were removed, and allowed to stand in the same fixative for 8 hours at $4^{\circ} \mathrm{C}$, then rinsed several times with PBS, and kept at $4{ }^{\circ} \mathrm{C}$ in PBS with $0.2 \%$ sodium azide until use.

\section{Histopathological examination}

The formalin-fixed brain tissues were embedded in paraffin, sliced at $6 \mu \mathrm{m}$ thickness, mounted on silanized slides, and subjected to hematoxylin and eosin staining according to the routine histopathological methods. Histopathological changes were observed under an Olympus Type BX51 microscopy.

\section{Immunohistochemical study}

We produced specific anti-8-nitroguanine antibody using 8-nitroguanine-RSA-conjugates. Rabbit polyclonal anti-8-nitroguanine antibody without cross reaction was produced as described previously $[10,11]$. The antibody was purified using an 8-nitroguanine-conjugate column. Specificity of the purified antibody was examined by a dot immunobinding assay and absorption test [10]. Purified antibody gave a strong immunostaining only on the spot of 8-nitroguanine conjugate. The immunoreactivity disappeared only when the antibody was pre-incubated with 8-nitroguanine. In contrast, immunoreactivity with 8-nitroguanine conjugate did not disappear when the antibody was pre-incubated with 3-nitrotyrosine, guanosine, 8-oxodG, deoxyguanosine, 8-bromoguanosine, and xanthosine. This purified antibody was presented the immunoreactivity with free or DNA-associated 8-nitroguanine both. 8-Nitroguanine immunoreactivities in the mouse brain sections were assessed by a peroxidase anti-peroxidase (PAP) method study as described previously [12]. Briefly, paraffin sections $(6-\mu \mathrm{m}$ thickness) were incubated with rabbit polyclonal anti-8-nitroguanine antibody $(2 \mu \mathrm{g} / \mathrm{ml})$ overnight at room temperature. Then, the sections were incubated for 3 hours with goat antibody against rabbit IgG (1:200), and were followed by peroxidase anti-peroxidase complex (1:200). The sections that had been treated with first and second antibodies were incubated for $10 \mathrm{~min}$ at RT with 3,3'diaminobentidine tetrahydrochloride (Dojindo Chemical Institute; Kumamoto, Japan) as chromogen, which had been freshly prepared as a solution of $20 \mathrm{mg}$ in $100 \mathrm{ml}$ PBS that contained $0.01 \% \mathrm{H}_{2} \mathrm{O}_{2}$. 


\section{Statistical analysis}

The experimental results are expressed as the mean \pm S.E.M. for twenty mice in each group, and the significant difference was analyzed by Student's t-test. A $P$ value of $<0.05$ was considered to be statistically significant. We analyzed the correlations of the number of 8-nitroguanine immunopositive cell in each experiment group.

\section{Results}

\section{Quantitative analysis of the experimental animals}

All the 60 mice were involved in the analysis of results without deletion. Alteration of histopathological study in the brain tissues of mice administrated with arsenic or arsenic/taurine (Fig. 1).

In the hematoxylin and eosin stained brain sections, well stained neurons with a distinct nucleus and nucleolus along with well-stained Nissl substance in the cytoplasm formed a prominent feature of the cerebra and cerebella in the control group. The neuronal processes as well as the neuropile appeared well formed in the control group. Microscopic observations of arsenic administrated group brain sections revealed structural degeneration of neuron. The cerebral neuron cells of the mice exposed to arsenic showed cell swelling and evident vacuolar degeneration in cytoplasm and nucleus, karyorrhexis and karyolysis. Relatively light pathological changes were showed in the nervous cells of the mice administered both of arsenic and taurine.

\section{Formation of 8-nitroguanine in brain tissue of mice}

8 -nitroguanine immunoreactivity in the brain tissue of mice is shown in Fig. 2. Little or no expression of 8nitroguanine in brain tissue was observed in control group (Fig. 2, Control). However, intensive expression of 8-nitroguanine was found in brain cells (Fig. 2, Arsenic) of mice exposed to arsenic. There was a tendency that 8-nitroguanine was localized in the neuron cells, whereas it was primarily distributed in the nucleus neighboring the nuclei membrane. The density and number of immunopositive cells were decreased in brain of mice administered both arsenic and taurine. Weak expression of 8-nitroguanine immunoreactivity was observed in neuron cells of mice that were administered both arsenic and taurine (Fig. 2, Arsenic + Taurine). In the cerebella, intensive expression of 8-nitroguanine was found in the Purkinje's cells and granule cells. Relatively weak expression of 8-nitroguanine immunopositive cells was observed in granule cells of the cerebella that were administered both of arsenic and taurine.

\section{Quantitative analysis of the formation of 8-nitroguanine} in the mice cerebrum

We counted the number of immunopositive neuron cells in the arsenic administrated group, arsenic/taurine administrated group and control group that exhibited immunoreactivity of 8-nitroguanine. Quantitative analysis of anti 8-nitroguanine staining neuron cells showed that the average immunopositive cells in brain tissue

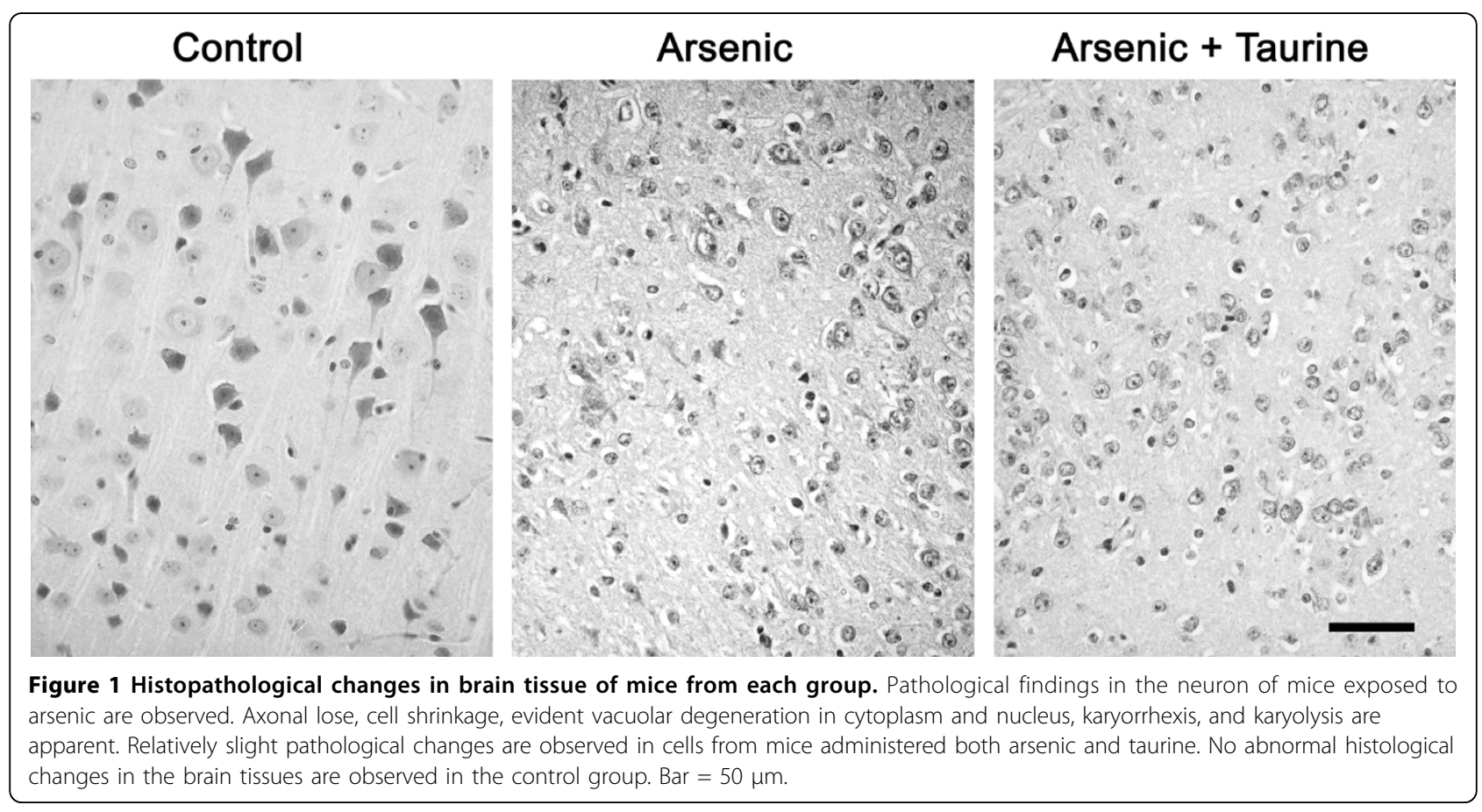




\section{Cerebrum}
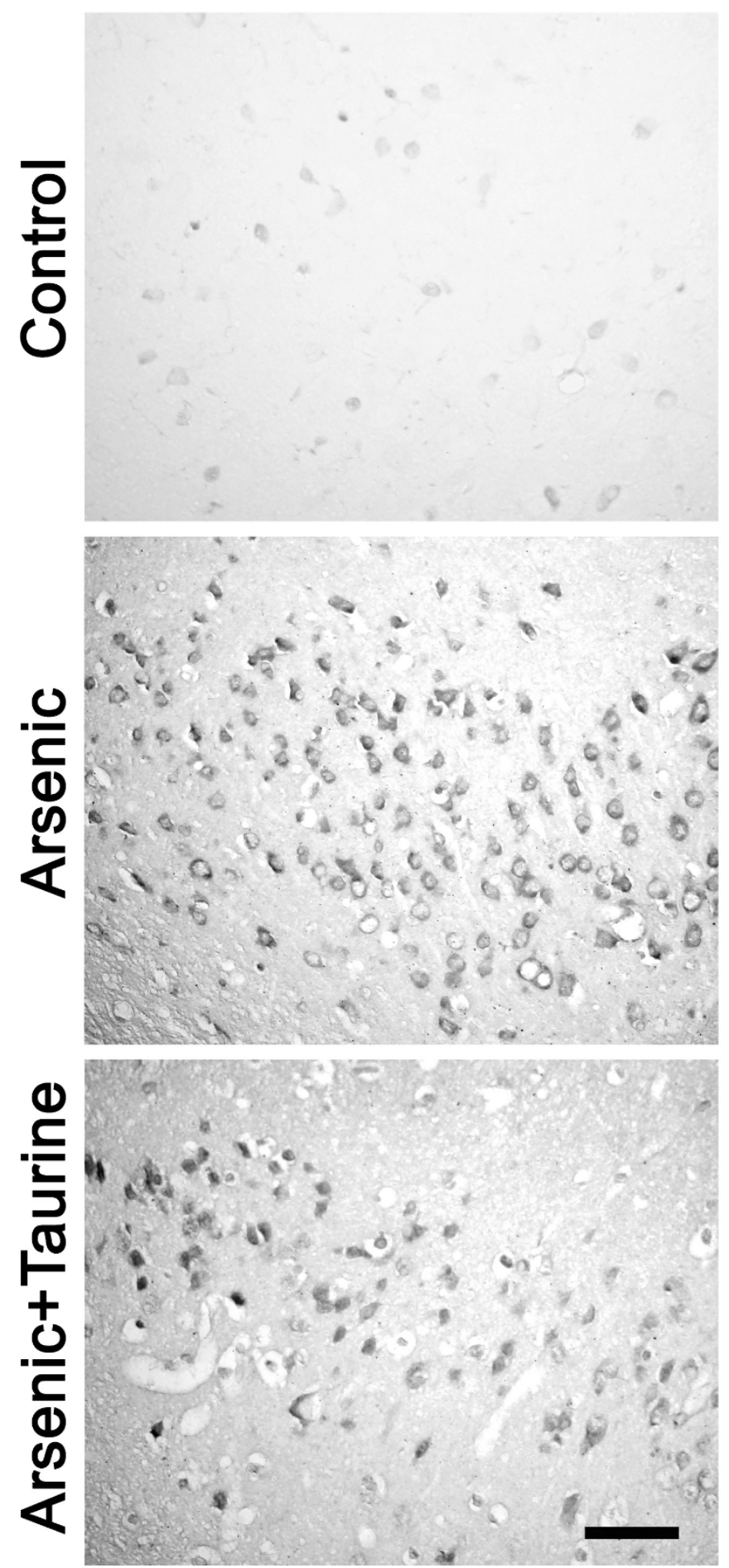

Figure 2 8-Nitroguanine immunoreactivity in the neuron of cerebrum and cerebellum of mice from each group. Little or no expression of 8-nitroguanine in brain tissue was observed in control group. Intensive expression of 8-nitroguanine was found in neuron cells in the cerebral cortex exposed to arsenic. Significantly elevated 8-nitroguanine immunoreactivity is observed in the granular cells of cerebellum of mice exposed to arsenic; 8-nitroguanine expression was primarily distributed in the nucleus. The density and number of 8-nitroguanine immunopositive cells were decreased in the cerebellum of mice administered both arsenic and taurine. Little or no 8-nitroguanine expression was observed in the cerebellum of control group. Bar: Cerebrum $=100 \mu \mathrm{m}$. Cerebellum $=200 \mu \mathrm{m}$. 
were significantly higher in the group exposed to arsenic than those in the other groups $(p<0.01)$ as shown in Fig. 3.

\section{Discussion}

Although many researches have demonstrated that arsenic is a neurotoxin substance [13-16], the mechanism of arsenic-induced neurotoxicity is not so clear. Chaudhuri et al. reported that in neonatal rat brain cells and human fetal brain cells, NO production was increased after arsenic treatment [17]. Ding et al. reported that arsenic induces nitric oxide generation through activation of inducible nitric oxide synthase (iNOS). Excessive production of nitric oxide has been implicated in neurodegenerative diseases [18]. It indicated that arsenic can induce overproduction of $\mathrm{NO}$ by inducing nitric oxide in the brain. A high concentration of NO reacts with oxyradical to product RNS including ONOO-, resulting in derangement of cell metabolism, breakage of DNA/RNA chains and tissue damage [19]. 8 -Nitroguanine is a product of nucleic acid, which has been previously damaged by reactive nitrogen species resulting in further mutations and carcinogenesis $[7,8,20]$. In the present study, strong expression of 8 nitroguanine was shown in cerebral cortex and cerebella cortex of mice exposed to arsenic sub-chronically.

Our results showed that in the nucleus, where DNA resides, very intense 8-nitroguanine was present;

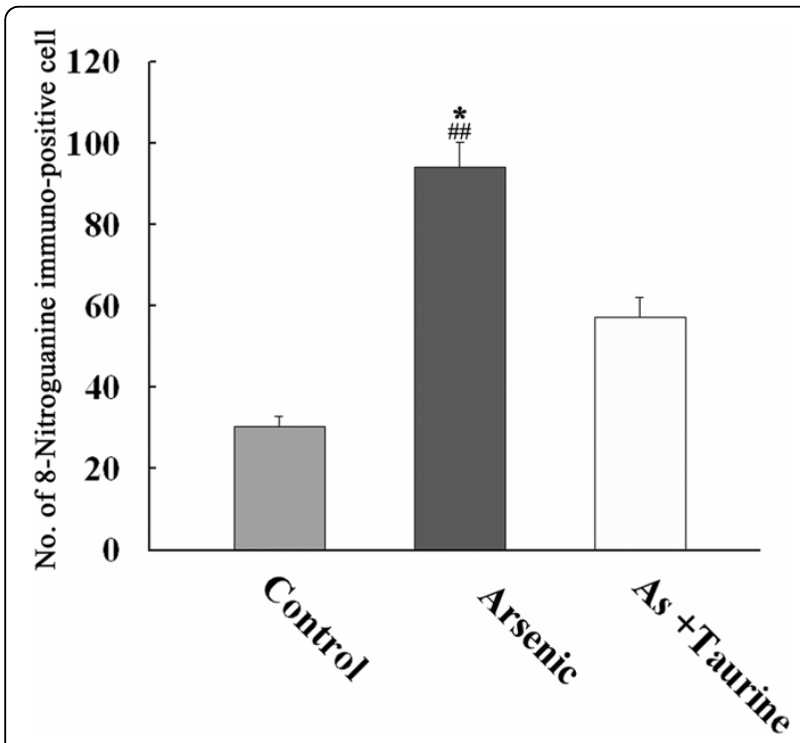

Figure 3 Effect of taurine on the formation of 8-nitroguanine in the cerebral cortex of mice brain exposed to arsenic. 8Nitroguanine immunopositive cells in the cortex of mice brain in the control, arsenic and arsenic/taurine. Each microscopic scoring damage value represents the mean \pm S.E.M of 10 microscopic fields in each animal. ${ }^{*} P<0.01$ compared with the control group, and ${ }^{\# \#} P$ $<0.01$ compared with the arsenic+taurine group. whereas in the cytoplasm, the occupational location of RNA, a weak 8-nitroguanine signal was detected. Because 8-nitroguanine has a strong expression in neuron cells exposed to arsenic, it may be associated with DNA damage of nerve cells by arsenic. These results suggested that arsenic exposure may lead to nucleic acid damage in neuron cells. Moreover, 8-nitroguanine staining results demonstrated that 8-nitroguanine was presented much stronger in the nucleus than in the cytoplasm. 8-Nitroguanine exhibits rapid depurination in cells, and it is more stable in RNA than in DNA [21] indicating that strong expression of strong expression of 8-nitroguanine in arsenic exposure may be associated with both DNA/RNA damage in the neural cells. Our previous studies had reported that exposure to arsenic induced oxidative DNA damage of neurons in cerebral cortex [22]. These results implied that neurons of cerebral and cerebellum cortex may be the major target cells of arsenic neurotoxicity.

Taurine is the most abundant free amino acid in many tissues and has protection against adverse effect of ROS caused by various toxic substances [23-26]. The results showed relatively light pathological changes and weak expression of 8-nitroguanine in nervous cells of the mice administered both arsenic and taurine. It was indicated that administration of taurine can alleviate pathological changes and DNA damage caused by arsenic through the RNS signal pathway. The protections of taurine may be associated with the reduction of oxyradicals so as to prevent the reaction of $\mathrm{NO}$ with oxyradicals to overproduce $\mathrm{ONOO}^{-}$. Taurine has been shown to inhibit iNOS expression in phagocytes, resulting in suppressed nitric oxide production [27]. For example, arsenic-induced neuron damage is related to inflammation, NO, and apoptosis, and many factors (such as iNOS, $\mathrm{ONOO}^{-}$, etc) are related to the cause of DNA damage. In this way, we speculate that the correction of these molecules and morphological changes may lead to neurobehavioral improvement in patients, thus, the treatment using taurine may represent an ideal approach for improving function after chronic exposure to arsenate in drinking water. In order to clarify the functional role of the 8-nitroguanine, quantifiable method for various $\mathrm{NO}$-mediated carcinogenesis models is under way in our laboratory.

\section{Conclusion}

The most important findings of this study suggest that the neuroprotective effect of taurine against pathological changes and nucleic acid damage is due to reactive nitrogen species in cerebrum and cerebellum of mice exposed to arsenic. The effects are probably mediated by the inhibition of inflammatory responses (i.e., iNOS). Taurine itself possessed either free radical scavenging or 
antioxidative activity, whereas it may reduce superoxide anion formation probably through inhibiting neutrophil activation. We speculate that the correction of these molecules and morphological changes may lead to neurobehavioral improvement in patients, thus, the treatment using taurine may represent an ideal approach for improving function after chronic exposure to arsenate in drinking water.

\section{Acknowledgements}

This work was supported partly by Otsuka Pharmaceutical Co., Ltd., and grants from the Ministry of Education, Culture, Sports, Science, and Technology of Japan to NM.

This article has been published as part as part of Journal of Biomedical Science Volume 17 Supplement 1, 2010: Proceedings of the 17th International Meeting of Taurine. The full contents of the supplement are available online at http://www.jbiomedsci.com/supplements/17/S1.

\section{Author details}

${ }^{1}$ Faculty of Health Science and Institute of Traditional Chinese Medicine, Suzuka University of Medical Science, Suzuka, Mie 510-0293, Japan. ${ }^{2}$ Department of Ophthalmology, Mie University Graduate School of Medicine, Tsu 514-0001, Mie, Japan. ${ }^{3}$ Department of Hygiene, Dalian Medical University, Dalian 116027, China.

\section{Authors' contributions}

NM carried out the antibody preparation and immunohistochemistry and drafted the manuscript. MS carried out the statistical analysis, participated in the immunohistochemical analysis. SK conceived of the study, and participated in its design. HS carried out the animal study and participated in tissue preparation. FP carried out the animal study, participated in tissue preparation, and participated in its design.

\section{Competing interests}

The authors declare that they have no competing interests.

Published: 24 August 2010

\section{References}

1. Tchounwou PB, Wilson B, Ishague A: Important considerations in the development of public health advisories for arsenic and arseniccontaining compounds in drinking water. Rev. Environ. Health 1999, 14:211-229.

2. World Health Organization (WHO): Guidelines for Drinking Water Quality. WHO Geneva, second41-42.

3. Hall AH: Chronic arsenic poisoning. Toxicol Lett 2002, 128(z):69-72.

4. Ahmad SA, Sayed MH, Barua S, Khan MH, Faruquee MH, Jalil A, Hadi SA, Talukder HK: Arsenic in drinking water and pregnancy outcomes. Environ Health Perspect 2001, 109:629-631.

5. Ratnaike RN: Acute and chronic arsenic toxicity. Postgrad Med J 2003, 79:391-396.

6. Roddriguez VM, Carrizales L, Mendoza MS, Fajardo OR, Giordano M: Effects of sodium arsenite exposure on development and behavior in the rat. Neurotoxicol Teratol 2002, 24:743-750.

7. Mishra D, Flora SJ: Differential oxidative stress and DNA damage in rat brain regions and blood following chronic arsenic exposure. Toxicol Ind Health 2008, 24:247-256.

8. Kawanishi S, Hiraku Y, Pinlaor S, Ma N: Oxidative and nitrative DNA damage in animals and patients with inflammatory diseases in relation to inflammation-related carcinogenesis. Biol Chem 2006, 387:365-372.

9. Kawanishi S, Hiraku Y: Oxidative and nitrative DNA damage as biomarker for carcinogenesis with special reference to inflammation. Antioxid Redox Signal 2006, 8:1047-1058

10. Pinlaor $S$, Hiraku $Y, M a ~ N$, Yongvanit $P$, Semba R, Oikawa S, Murata M, Sripa B, Sithithaworn P, Kawanishi S: Mechanism of NO-mediated oxidative and nitrative DNA damage in hamsters infected with
Opisthorchis viverrini: a model of inflammation-mediated carcinogenesis. Nitric Oxide 2004, 11:175-183.

11. Pinlaor $S, M a N$, Hiraku $Y$, Yongvanit $P$, Semba R, Oikawa S, Murata M, Sripa B, Sithithaworn P, Kawanishi S: Repeated infection with Opisthorchis viverrini induces accumulation of 8-nitroguanine and 8-oxo-7, 8-dihydro$2^{\prime}$-deoxyguanine in the bile duct of hamsters via inducible nitric oxide synthase. Carcinogenesis 2004, 25:1535-1542.

12. Ma N, Aoki E, Semba R: An immunohistochemical study of aspartate, glutamate, and taurine in rat kidney. J Histochem Cytochem 1994, 42:621-626.

13. Luo JH, Qiu ZQ, Shu WQ, Zhang YY, Zhang L, Chen JA: Effects of arsenic exposure from drinking water on spatial memory, ultra-structures and NMDAR gene expression of hippocampus in rats. Toxicol Lett 2009, 184:121-125.

14. Dhar P, Mohari N, Mehra RD: Preliminary morphological and morphometric study of rat cerebellum following sodium arsenite exposure during rapid brain growth (RBG) period. Toxicology 2007, 234:10-20.

15. Haider SS, Najar MS: Arsenic induces oxidative stress, sphingolipidosis, depletes proteins and some antioxidants in various regions of rat brain. Kathmandu Univ Med J (KUMJ) 2008, 6:60-69

16. Kanan GM, Tripathi N, Dube SN, Gupta M, Flora SJ: Toxic effects of arsenic (III) on some hematopoietic and central nervous system variables in rats and guinea pigs. J Toxicol Clin Toxicol 2001, 39:675-682.

17. Chaudhuri AN, Basu S, Chattopadhyay S, Das Gupta S: Effect of high arsenic content in drinking water on rat brain. Indian J Biochem Biophys 1999, 36:51-54.

18. Ding W, Hudson LG, Sun X, Feng C, Liu KJ: As(III) inhibits ultraviolet radiation-induced cyclobutane pyrimidine dimmer repair via generation of nitric oxide in human keratinocytes. Free Radic Biol Med 2008, 45:1065-1072.

19. Gurr JR, Yih LH, Samikkannu T, Bau DT, Lin SY, Jan KY, Hsing Wu College, Fen-Liao Rd, Lin-Kou Taipei, 244, Taiwan, ROC: Nitric oxide production by arsenite. Mutat Res 2003, 533:173-182.

20. Hemnani T, Parihar MS: Reactive oxygen species and oxidative DNA damage. Indian J Physiol Pharmacol 1998, 42:440-452.

21. Giris M, Depboylu B, Dogru-Abbasoglu S, Erbil Y, Olgaç V, Aliş H, AykaçToker G, Uysal M: Effect of taurine on oxidative stress and apoptosisrelated protein expression in trinitrobenzene sulphonic acid-induced colitis. Clin Exp Immunol 2008, 152:102-110.

22. Piao F, Ma N, Hiraku Y, Murata M, Oikawa S, Cheng F, Zhong L, Yamauchi T, Kawanishi S, Yokoyama K: Oxidative DNA damage in relation to neurotoxicity in the brain of mice exposed to arsenic at environmentally relevant levels. J Occup Health 2005, 47:445-449.

23. Ritz MF, Curin Y, Mendelowitsch A, Andriantsitohaina R: Acute treatment with red wine polyphenols protects from ischemia-induced excitotoxicity, energy failure and oxidative stress in rats. Brain Res 2008, 1239:226-234.

24. Li F, Abatan OI, Kim H, Burnett D, Larkin D, Obrosova IG, Stevens MJ: Taurine reverses neurological and neurovascular deficits in Zucker diabetic fatty rats. Neurobiol Dis 2006, 22:669-676.

25. Vohra BP, Hui X: Taurine protects against carbon tetrachloride toxicity in the cultured neurons and in vivo. Arch Physiol Biochem 2001, 109:90-94.

26. Saransaari P, Oja SS: Taurine and neural cell damage. Amino Acids. 2000, 19:509-526.

27. Kim C, Cha YN: Production of reactive oxygen and nitrogen species in phagocytes is regulated by taurine chloramines. Adv Exp Med Biol 2009, 643:463-472.

doi:10.1186/1423-0127-17-S1-S7

Cite this article as: Ma et al:: Protection effect of taurine on nitrosative stress in the mice brain with chronic exposure to arsenic. Journal of Biomedical Science 2010 17(Suppl 1):S7. 